\title{
TOXICITY OF TWO ORGANOPHOSPHOROUS PESTICIDES ON BIGHEAD CARP (ARISTICHTHYS NOBILIS RICHARDSON, 1845) LIVER
}

\author{
YANChEVA, V. ${ }^{1}$ - VelcheVA, I. ${ }^{1}-$ StOYANOVA, S. ${ }^{2 *}-$ ILIEV, I. ${ }^{3}-$ VASILEVA, T. ${ }^{3}-$ \\ BIVOLARSKI, V. ${ }^{3}-$ UCHIKOVA, E. $^{4}-$ GEORGIEVA, E. $^{2}$ \\ Plovdiv University, Faculty of Biology, Plovdiv, 4000, Bulgaria \\ ${ }^{1}$ Department of Ecology and Environmental Conservation, ${ }^{2}$ Department of Developmental \\ Biology, ${ }^{3}$ Department of Biochemistry and Microbiology, \\ ${ }^{4}$ Medical University, Plovdiv, 4000, Bulgaria \\ *Corresponding author: \\ e-mail: stela.st@abv.bg \\ (Received 10 $0^{\text {th }}$ Aug 2015; accepted $11^{\text {th }}$ Nov 2015)
}

\begin{abstract}
In the present work two different pesticides, a herbicide and a fungicide were used in order to study their toxic effects on bighead carp (Aristichthys nobilis Rich.). We investigated the fish liver as a main detoxification organ and observed its morphological structure. In addition, we also measured the hepatic enzymatic activity of LDH, ALAT and ASAT. The histological lesions were degenerative and necrotic changes, as well as changes in the circulatory system. The degenerative changes included granular, balloon, fatty and hyaline degeneration. The necrotic changes included necrobiosis and necrosis, and the changes in the circulatory system - hyperemia and lymphocyte proliferation, respectively. The levels of LDH, ALAT and ASAT were altered compared to the control. Thus, we can conclude that both selected pesticides have a negative impact on the fish liver function. However, the fungicide exposure led to more pronounced histological alterations.
\end{abstract}

Keywords: pesticides, Aristichthys nobilis, histology, enzymes, water contamination

Acronyms: $L D H$ - lactate dehydrogenase, ALAT - alanine aminotransferase, ASAT - aspartate aminotransferase

\section{Introduction}

In the European Union, there are more than 100.000 registered chemicals, of which 30.000-70.000 are in daily use (EINECS, European Inventory of Existing Chemical Substances) (Schwarzenbach et al., 2006). The pesticides are among these chemicals, which have been found ubiquitously in natural waters, not only in industrialized areas, but also in more remote environments (Loos et al., 2010; Yadav et al., 2010). Thus, the widespread use of pesticides for agricultural activities results in the contamination of numerous aquatic ecosystems, including water, sediments and biota (Devault et al., 2009).

In this sense, organophosphorous pesticides (OPs) in many cases replaced organochlorine pesticides (OCs) in agriculture. Even though they have a short-term degradation and fewer residues, OPs unfortunately lack target specificity and can cause severe, long lasting population effects on aquatic non-target species (Fulton and Key, 2001). Furthermore, according to Solé et al. (2000) the OPs rapidly degrade in the water column and biota, and are considered as low persistent chemicals. However, concern remains for non-target organisms, particularly within coastal areas, which are characterised by poor water circulation and during periods of intensive agricultural activity. In addition, the OPs are potentially harmful for aquatic organisms due to 
prolonged inhibitory effects on the cholinesterase (ChE) activity (Valbonesi et al., 2011) and capability to induce other physiological disorders (Almeida et al. 2010). In addition, the OP residues can concentrate and diffuse by the effect of biological enrichment and food chains; therefore they might appear in food products and pose a potential risk for human health (Sun et al., 2011).

According to Reemtsma et al. (2006) some chemicals are not degraded at all (e.g., heavy metals) or only very slowly (e.g., persistent organic pollutants such as DDT, lindane, EDTA, perfluorinated acids (PFAs), or even some pharmaceuticals such as carbamazepine or sulfamethoxazole. Hence, to tackle the problems with water contamination the European Water Framework Directive (WFD) (2001) sets up environmental objectives to achieve "good water status" for all European waters by 2015, and establishes a clear framework to enable these objectives to be achieved.

Furthermore, according to the WFD the fish represent one of the key elements to evaluate the rivers ecological status and they are among the group of non-target aquatic organisms (Hermoso et al., 2010; Marin-Morales et al., 2013). The fish provide a good model for monitoring the toxicity in aquatic systems because they are extremely sensitive to pollutants, have the ability to metabolize xenobiotics and exhibit a very high bioaccumulation rate of dissolved chemicals relative to their concentration. Moreover, the fish is a valuable bioindicator, because its detoxification enzymes (e.g. monooxygenases) have a lower activity than in mammals and thus, allows a higher toxicant bioaccumulation (Zhou et al., 2008; Fazio et al., 2013). According to Kroglund et al. (2008) the toxicant concentrations, particularly in the gills reflect the toxicant concentrations in the water where the fish live; whereas the concentrations in parenchymal organs such as the liver and kidney represent storage of toxicants. Thus, the fish liver, which is the primary organ for metabolism, detoxification of xenobiotics and excretion of harmful substances, is one of the most common organs studied in ecotoxicological research. It also has the ability to degrade toxic compounds, but its regulating mechanisms can be overwhelmed by elevated concentrations of these compounds, and could subsequently result in structural damages (Bruslé and Gonzalez, 1996; Au, 2004; Mohamed, 2009).

Viana et al. (2013) and Pinheiro-Sousa et al. (2013) suggest that the biomonitoring process should include analyses at different levels of biological organization, from subcellular and cellular analysis of tissues and organs, to those of population and community levels. Therefore, Van der Oost et al. (2003) define biomarkers as biological indicators from an exposure to a stressor responding in various ways, which can be successfully applied in environmental biomonitoring and risk assessment programs. Histology is an important diagnostic and sensitive tool to detect direct effects of chemical compounds on target organs and can therefore, be used to assess the health of fish populations in contaminated aquatic systems (Schwaiger et al., 1997; Van Dyk and Pieterse, 2008; Sousa et al., 2013a; Sousa, 2013b). Severe or prolonged physiological and biochemical alterations will lead to structural alterations, which will become more pronounced over time and the severity will increase (Van Dyk et al., 2009). Antioxidant enzymes in the fish liver are also considered to be important parameters for testing water quality and negative effects of pesticides, as well as for detecting potential adverse effects and relatively early events of pollutant damage (Stentiford et al., 2003; Koenig et al., 2012). Hence, various responses of enzymes have been observed in fish exposed to different persistent organic contaminants, which indicate an increase or a decrease in the activity depending on the dose, species and route of exposure (Lu et al., 2013). 
The main objective of the present experiment was to study ex situ the toxic effects of two organophosphorous pesticides (herbicide and fungicide) on the liver of bighead carp (Aristichthys nobilis Richardson, 1845). We aimed to determine, which one of the two tested pesticides has a more severe impact on its structure and functions. Such data is relatively scarce, even though the toxic effects of pesticides on fish are well-studied. For this purpose in the present study we investigated the hepatic histological structure and activity of the enzymes LDH, ALAT and ASAT.

\section{Materials and methods}

\section{Test chemicals}

\section{Fungicide}

We used in the present study a fosetyl-Al (Aluminium tris-O-ethyl phosphonate) and fenamidone (1-anilino-4-methyl-2-methylthio-4-phenylimidazolin-5-one) based fungicide in the form of dispersible granules (WG). According to European Food Safety Authority (2006) fosetyl-Al is a phosphonate compound, but its structure and mode of action differ from the most of the other organophosphorus compounds used as pesticides. Moreover, fosetyl-Al is used for control of various plant pathogenic phycomycetes and ascomycetes. This active substance is used for preventing crops and also for inhibiting fungal spore germination and penetration of pathogens into plants. Fosetyl-Al also acts indirectly by stimulating the plant's natural defence mechanisms. Fenamidone belongs to the Quinone outside Inhibitors (QoI) group (Genix et al., 2003) and provides an excellent control of Oomycetes diseases (Leake, 2003).

\section{Herbicide}

The test herbicide is a glyphosate ( $\mathrm{N}$-(phosphonomethyl)-glycine) based one. Glyphosate is an aminophosphonic analogue of the natural amino acid glycine and it is commonly formulated in its form of isopropylamine salt (IPA salt), though other related chemical forms are also commercialized (Franz, 1985). It is a systemic herbicide that is readily translocated throughout the plant.

We used concentrations of $30 \mathrm{mg} / \mathrm{l}, 38 \mathrm{mg} / \mathrm{l}$ and $50 \mathrm{mg} / \mathrm{l}$ fungicide; as well as 20 $\mathrm{mg} / \mathrm{l}, 40 \mathrm{mg} / \mathrm{l}$ and $72 \mathrm{mg} / \mathrm{l}$ herbicide. The chemical concentrations represent 50, 40, 30 times dilution (for the fungicide) and 70, 40, 20 times dilution (for the herbicide) of the stock solution, which were prepared according to the guidelines for application by the manufacturer.

\section{Test animals}

Bighead carp (Aristichthys nobilis) is a freshwater cyprinid fish species, which has become very popular in the last years in aquaculture and sports fishing. However, there is not enough ecotoxicological data on bighead carp as the most commonly used cyprinid fish in such studies are common carp (Cyprinus carpio) and gibel carp (Carassius gibelio).

We purchased seventy healthy fish from the "Institute of Fisheries and Aquaculture" in the city of Plovdiv, Bulgaria. The bighead carps were with similar size (mean length $18.65 \mathrm{~cm} \pm 1.33$; mean body mass $53.02 \mathrm{~g} \pm 6.3$ ) with no external pathological abnormalities. The fish were transported in plastic tanks equipped with air pumps to the 
laboratory at the department of Ecology, Faculty of Biology, University of Plovdiv. Thereafter, they were placed in 1001 tanks with chlorine-free tap water (by evaporation) in order to acclimatize for one week. The laboratory experiment included 6 tanks with 10 bighead carps exposed to 6 different pesticide concentrations ( 3 for each pesticide as described above). The seventh tank served for control. The fish were not fed prior or during the $96 \mathrm{~h}$ experiment.

All tanks were equipped with air pumps for permanent aeration and the water was kept oxygen saturated. The fish were kept under a natural light/dark cycle (12:12). The water physico-chemical characteristics such as $\mathrm{pH}$, temperature, dissolved oxygen and oxygen saturation, and conductivity were measured once per day according to a standard procedure (APHA, 2005) with a combined field meter (WTW, Germany). They were as follows: $\mathrm{pH}-8.1 \pm 0.5$; temperature $-21.5 \pm 1.5^{\circ} \mathrm{C}$; dissolved oxygen $7.3 \pm 2.5 \mathrm{mg} / \mathrm{l}$, oxygen saturation $-103.5 \pm 1.2 \%$ and conductivity $-423 \pm 1.5 \mu \mathrm{S} / \mathrm{cm}$.

The present study was performed in accordance with national and international guidelines of the European Parliament and the Council on the protection of animals used for scientific purposes (Directive 2010/63/EU).

\section{Histological analysis}

The liver samples were prepared for histological analysis using standard techniques (Romeis, 1989). After dissection they were immediately fixed in 10\% neutrally buffered formalin solution for $24 \mathrm{~h}$. The preserved samples were washed in tap water, dehydrated in a series of increasing ethanol concentrations $(70 \%-80 \%-85 \%-96 \%-100 \%)$, cleared in xylene, infiltrated with liquid paraffin with a melting point of $54-56^{\circ} \mathrm{C}$ and finally embedded in paraffin wax, sectioned at 5-7 $\mu \mathrm{m}$ thick cut using a semi-automated rotary microtome (Leica RM 2245, Germany) and mounted on sterilized glass slides. The samples were then deparaffinised, stained with hematoxylin and eosin (H\&E) and prepared for light microscopy analysis. The histological changes in the liver were observed and photographed using a light microscope (Nikon, Japan) mounted with a digital camera.

\section{Assessment of histological alterations}

A histological assessment protocol of Van Dyk et al. (2009) was used to estimate the histological lesions identified in the livers of all exposed fish. In addition, we modified and combined the semi-qualitative histological grading systems by Pierce et al. (1978) and Zimmerli et al. (2007) where a numerical value (grade) was assigned to each liver according to its histological characteristics. This system clearly distinguishes between the normal liver morphology and pathology by indicating the histological conditions associated with healthy and pathological conditions.

Each grade represents specific histological characteristics and is assigned from 0 to 5 as follows: 0 - normal/healthy structure; the tissue architecture is well developed and show no impairments or pathological changes; 1 - normal/healthy structure with slight degenerative changes in the hepatocytes, as well changes in the circulatory system; 2 normal hepatic structure with mild degenerative changes in the hepatocytes, as well changes in the circulatory system; 3 - hepatic alterations with moderate degenerative changes in hepatocytes, as well as changes in the circulatory system; 4 - pronounced degenerative changes in the hepatocytes, as well as changes in the circulatory system; 5 - very severe hepatic alterations, loss of hepatic cord structure. 


\section{Biochemical analysis}

The livers were rapidly thawed on ice and manually homogenized, using a Potter Elvehjem homogenizer fitted with a Teflon pestle in chilled phosphate buffer $(50 \mathrm{mM}$, $300 \mathrm{mM} \mathrm{NaCl}, \mathrm{pH}$ 7.4). The homogenates was subjected to centrifugation at $9000 \mathrm{rpm}$ for $15 \mathrm{~min}$. in a cooling centrifuge (MPW $351 \mathrm{R}$, Poland) at $4{ }^{\circ} \mathrm{C}$. The supernatant fractions were aliquoted, transferred in new eppendorf tubes and stored at $-80^{\circ} \mathrm{C}$ for further enzyme assays. All biochemical assays were measured spectrophotometrically (Beckman Coulter Spectrophotometer DU 800, USA) at $25^{\circ} \mathrm{C}$. The chemicals used in this study were purchased from Sigma Chemical Co. and were of analytical grade.

The lactate dehydrogenase (LDH, E.C. 1.1.1.27) activity was assayed according to Vassault (1983). The aspartate aminotransferase (ASAT, E.C. 2.6.1.1) and alanine aminotransferase (ALAT, E.C. 2.6.1.2) activities were determined by the method of Reitman and Frankel (1957) as described by IFCC (1986) using commercially available kits.

The protein levels were measured by the Bradford (1976) method with Coomassie Brilliant Blue G-250 using bovine serum albumin as standard. The absorbance of samples was detected at $595 \mathrm{~nm}$ and expressed as milligram protein per millilitre homogenate.

One unit of LDH, ASAT and ALAT was defined as the amount of the enzyme that consumes $1 \mathrm{~mol} / \mathrm{l}$ of substrate or generates $1 \mathrm{~mol} / \mathrm{l}$ of product per min. The activity was expressed in international units per milligram of protein.

The statistical analyses on raw data on the different pesticide concentrations and control group were tested using the Student's t-test $(\mathrm{p}<0.05)$ and software program Statistica (version 7.0 for Windows, StatSoft, 2004). The data of analyses were reported as mean \pm SD.

\section{Results}

\section{Liver histology}

The present study demonstrates that the control fish liver generally exhibited normal morphology with a typical parenchymatous appearance and there were no pathological abnormalities found. The parenchyma was primarily composed of hepatocytes typically with a large central nucleus and homogenous cytoplasm. In very rare cases the fish hepatocytes can be found with two nuclei. The hepatocytes were located among blood sinusoids forming a cord-like structure known as hepatic cell cords. The lumen of sinusoids contained mainly erythrocytes. The venous blood entered the liver caudally from the intestine via the hepatic portal veins and branches into the sinusoids. They were lined with reticuloendothelial cells, which were in turn surrounded by hepatocytes (Takashima and Hibiya, 1995).

On the other hand, the histological analysis, which was performed, showed degenerative and necrotic changes in the fish exposed to the two tested pesticides, as well as changes in the circulatory system (see Table 1). The degenerative changes included granular, balloon, fatty and hyaline degeneration (Fig. $1 \mathrm{~b}, \mathrm{~h}, \mathrm{i}$ ). The necrotic changes included necrobiosis and necrosis (Fig. 1b, f), and the changes in the circulatory changes - hyperemia and lymphocyte proliferation, respectively (Fig. 1d, e, $h, i$ ). 



Figure 1. Histological alterations in bighead carp liver due to pesticide exposure, $\boldsymbol{a}$ - control group, $x 200 ; \boldsymbol{b}$ - granular degeneration (black and white arrow), balloon degeneration (black arrow) and karyolysis (dashed arrow) at $30 \mathrm{mg} / \mathrm{l}$ fungicide, $x 400$; $\boldsymbol{c}$-hyaline degeneration at

$38 \mathrm{mg} / \mathrm{l}$ fungicide, $x 600 ; \boldsymbol{d}$-lymphocyte proliferation at $38 \mathrm{mg} / \mathrm{l}$ fungicide, $x 400 ; \boldsymbol{e}-$ hyperemia at $50 \mathrm{mg} / \mathrm{l}$ fungicide, $x 400 ; \boldsymbol{f}$-necrosis at $50 \mathrm{mg} / \mathrm{l}$ fungicide, $x 400 ; \boldsymbol{g}$ - granular degeneration (black and white arrow) and balloon degeneration (black arrow) at $20 \mathrm{mg} / \mathrm{l}$ herbicide, $x 400 ; \boldsymbol{h}$ - hyperemia (black arrow) and granular degeneration (black and white arrow) at $40 \mathrm{mg} / \mathrm{l}$ herbicide, $x 400$; $\boldsymbol{i}$ - granular degeneration (black and white arrow) and hyperemia (black arrow) at $72 \mathrm{mg} / \mathrm{l}$ herbicide, $x 400$.

In terms of the semi-quantitative scale in the fish exposed to the two pesticides we determined moderate (3) degenerative changes - granular, balloon and fatty degeneration, which were dose-dependent (Table 1). Only balloon degeneration in the fish exposed to the herbicide was expressed in a mild degree. We did not observe severe hepatic changes (described as 5) in our study.

When it comes to hyaline degeneration as a hepatic alteration, we found significant differences when we compared the effects of the two tested pesticides. This particular change was observed only in the fish exposed to the fungicide. On the other hand, the fish exposed to the herbicide did not show any single evidence for hyaline degeneration. At the lowest fungicide concentration this alteration was expressed only as some acidophilus droplets in the hepatocytes cytoplasm. When the fungicide concentrations increased, the number and size of the acidophilus droplets increased, respectively. Moreover, at the highest fungicide concentration we determined a combination of hyaline degeneration with karyolitic and necrotic sections. In general, the expression of 
hyaline degeneration was determined as pronounced, which was the most severe one compared with the other liver alterations (Fig. 1c).

In the liver structure we also observed necrobiotic and necrotic hepatocytes. They were mostly expressed in a mild to moderate degree. Necrosis in the liver parenchyma revealed also a tendency towards increasing its expression with increasing the toxicant concentrations. Interestingly, there was no significant difference in the extent of the expression between the effects of both pesticides (Table 1).

Table 1. Histological alterations in bighead carp liver due to pesticide exposure

\begin{tabular}{|c|c|c|c|c|c|c|c|}
\hline \multirow{2}{*}{$\begin{array}{l}\begin{array}{c}\text { Histological } \\
\text { alterations }\end{array} \\
\begin{array}{l}\text { Concentration } \\
\text { mg/l }\end{array}\end{array}$} & \multirow[t]{2}{*}{ Control } & \multicolumn{3}{|c|}{ Fungicide } & \multicolumn{3}{|c|}{ Herbicide } \\
\hline & & 30 & 38 & 50 & 20 & 40 & 72 \\
\hline $\begin{array}{l}\text { Granular } \\
\text { degeneration }\end{array}$ & 1 & 1 & 3 & 3 & 1 & 3 & 3 \\
\hline $\begin{array}{l}\text { Balloon } \\
\text { degeneration }\end{array}$ & 0 & 2 & 3 & 3 & 1 & 1 & 1 \\
\hline $\begin{array}{l}\text { Hyaline } \\
\text { degeneration }\end{array}$ & 0 & 2 & 3 & 4 & 0 & 0 & 0 \\
\hline $\begin{array}{l}\text { Fatty } \\
\text { degeneration }\end{array}$ & 0 & 1 & 2 & 3 & 1 & 1 & 2 \\
\hline $\begin{array}{l}\text { Necrotic } \\
\text { alterations: } \\
\text { kariopyknosis }\end{array}$ & 0 & 0 & 0 & 2 & 0 & 1 & 1 \\
\hline kariorrehiss & 0 & 0 & 0 & 0 & 0 & 0 & 1 \\
\hline kariolysis & 0 & 1 & 1 & 2 & 1 & 1 & 1 \\
\hline Necrosis & 0 & 1 & 2 & 2 & 1 & 2 & 2 \\
\hline $\begin{array}{l}\text { Lymphocyte } \\
\text { proliferation }\end{array}$ & 0 & 0 & 1 & 2 & 1 & 1 & 1 \\
\hline Hyperemia & 0 & 2 & 1 & 2 & 2 & 2 & 2 \\
\hline
\end{tabular}

The changes in the circulatory system such as hyperemia were observed more frequently in the sinusoids and less in the hepatic veins. The effects of the herbicide were more serious compared to the fungicide. As for the lymphocyte proliferation, the trend to increase the degree of expression was dose-dependent in the fish exposed to the fungicide, while in the fish exposed to the herbicide the degree of expression was maintained mild at all three used concentrations.

\section{Liver biochemistry}

In the present study we also measured the specific activity of three hepatic enzymes - LDH, ASAT and ALAT (Table 2). Any changes in their activity could provide information regarding the toxic effects of the studied pesticides, including tissue damage. 
In the fish exposed to the fungicide we observed an increase in the levels of LDH, ALAT and ASAT compared with the control group. The statistical analysis showed significant differences $(\mathrm{p}<0.05)$ for the activity of LDH between the control and the fish exposed to concentrations of $38 \mathrm{mg} / \mathrm{l}$ and $50 \mathrm{mg} / \mathrm{l}$. Such a difference $(\mathrm{p}<0.05)$ was also found for the activity of ASAT between the control and the highest fungicide concentration. There was also a significant difference $(p<0.05)$ for the activity of ALAT between the control and all three experimental concentrations (Table 2).

Similarly to the fish exposed to the test fungicide, there was an increase in the LDH levels in the fish treated with the herbicide compared with the control group. The aminotransferase activity decreased its values in a dose-dependent manner compared with the control group. The statistical analysis showed a significant difference ( $\mathrm{p}<$ 0.05 ) for the $\mathrm{LDH}$ values between the control and the fish exposed to $20 \mathrm{mg} / \mathrm{l}$ and 40 $\mathrm{mg} / \mathrm{l}$ herbicide concentrations. There was also a statistical difference $(\mathrm{p}<0.05)$ between the control and the fish treated with herbicide concentrations of $40 \mathrm{mg} / \mathrm{l}$ and $72 \mathrm{mg} / \mathrm{l}$ (Table 2).

Table 2. Enzymatic activity of LDH, ASAT and ALAT in bighead carp liver due to pesticide exposure

\begin{tabular}{|c|c|c|c|c|c|c|c|}
\hline \multirow[b]{2}{*}{$\begin{array}{c}\text { Fungicide } \\
\text { concentration }\end{array}$} & \multicolumn{7}{|c|}{ Enzymatic activity $\mathrm{U}$ mg/l protein (average \pm SD) } \\
\hline & LDH & ASAT & ALAT & $\begin{array}{c}\text { Herbicide } \\
\text { concentration }\end{array}$ & LDH & ASAT & ALAT \\
\hline Control & $0.93 \pm 0.05$ & $0.15 \pm 0.05$ & $0.32 \pm 0.03$ & Control & $0.35 \pm 0.05$ & $0.49 \pm 0.03$ & $0.41 \pm 0.05$ \\
\hline 30 mg/l & $1.26 \pm 0.03$ & $0.25 \pm 0.03$ & $0.61 \pm 0.06^{*}$ & $20 \mathrm{mg} / \mathrm{l}$ & $1.20 \pm 0.03 *$ & $0.30 \pm 0.03$ & $0.38 \pm 0.04$ \\
\hline $38 \mathrm{mg} / \mathrm{l}$ & $1.53 \pm 0.5^{*}$ & $0.32 \pm 0.04$ & $0.65 \pm 0.05^{*}$ & $40 \mathrm{mg} / \mathrm{l}$ & $0.98 \pm 0.04 *$ & $0.21 \pm 0.05^{*}$ & $0.26 \pm 0.05^{*}$ \\
\hline $50 \mathrm{mg} / \mathrm{l}$ & $1.73 \pm 1.5^{*}$ & $0.38 \pm 0.04 *$ & $0.58 \pm 0.04 *$ & $72 \mathrm{mg} / \mathrm{l}$ & $0.45 \pm 0.05$ & $0.13 \pm 0.05^{*}$ & $0.21 \pm 0.03 *$ \\
\hline
\end{tabular}

*enzymatic activity significantly different than the control $(\mathrm{p}<0.05)$

\section{Discussion}

The increasingly widespread use of pesticides in agriculture and their impact on nontarget aquatic organisms require specific studies on their effects on economically significant species such as bighead carp. It turns out that this particular fish has been gaining popularity in aquaculture in the last years, but surprisingly the ecotoxicological data regarding this fish species is quite scarce. Our results indicated that the bighead carp is a relatively sensitive cyprinid species in terms of pesticide intoxication compared for example with common carp (Cyprinus carpio) or gibel carp (Carassius gibelio).

Granular and balloon degeneration were the hepatic lesions, which were determined in the most pronounced degree in the fish treated with both pesticides. Our results are in agreement with other authors' who state that these tissue alterations are among the most common ones when it comes to pesticide effects (Jiraungkoorskul et al., 2003; Velmurugan et al., 2009). This is also true for the necrobiotic changes. In our experiment we found that the fungicide caused more severe degenerative changes compared with the herbicide.

At the highest fungicide concentration we observed less hyaline droplets, but necrosis was more pronounced. This in turn, indicates more toxic effects of the fungicide at this concentration compared to the previous, leading to a higher degree of 
necrotic changes in the hepatic parenchyma. We think that such irreversible disturbances in the hepatocytes suggests dystrophic changes in the protein metabolism, probably by immunological interactions between the fish organism and toxicant.

Necrosis was found in the fish exposed to both, fungicide and herbicide and its expression was dose-dependent. In general, the necrobiotic changes were expressed in a mild to moderate degree. Even though, we believe that the liver functions could be seriously altered. It is notable that both pesticides had the same toxic mode of action in terms of this particular hepatic lesion. Hepatic necrosis was also reported by Carvalho Neta et al. (2014) caused by organic toxicants on catfish.

Likewise Velmurugan et al. (2008) we consider that the changes in the hepatic enzymes represent a sensitive biochemical indicator for the negative pesticide effects. $\mathrm{LDH}$ is an enzyme, which takes part in the anaerobic pathway of carbohydrate metabolism (Banaee et al., 2013a). Furthermore, ALAT and ASAT are liver specific enzymes, participating in the amino acids metabolism. Balint (1997) also consider that they are sensitive indicators for hepatotoxicity and histological lesions. In the current study the changes in the hepatic LDH, ALAT and ASAT activity compared with the control confirmed the toxic impact of both, the fungicide and herbicide, which was also reported by Yousafzai and Shakoori (2011) in their study. In addition, we consider that the changes in the hepatic enzyme activities represent tissue damage due to altered permeability of the hepatocyte cells.

According to Almeida et al. (2002) when the fish is stressed, it needs additional energy, which will be used for detoxification processes. Thus, LDH participates in the production of energy by the way of anaerobic metabolism. According to Banaee et al. (2013b) the increase in the LDH levels activity is a widely used diagnostic index, which demonstrates energy depletion due to changes in the environmental conditions and impact of toxicants.

Das and Mukherjee (2003) registered an increased LDH activity in the liver of fish exposed to cypermethrin. Analogous results were also found by Sepici-Dincel et al. (2009) and Malarvizhi et al. (2012). In contrast, Mishra and Shukla (1997), Gabriel and George (2005) and Gabriel et al. (2012) determined a decreased LDH activity.

According to Morowati (1997) the changes in ALAT and ASAT activity can also be used successfully as biomarkers for hepatotoxicity. In addition, changes in the levels of ALAT have an important role in the glucose-alanine cycle in the liver. Banaee et al. (2012) consider that in a state of stress the increased ASAT and ALAT activity stimulate the gluconeogenesis process as they have an important role in the mobilization of L-amino acids.

Increased hepatic enzyme activity of ALAT and ASAT is determined by Neškovic et al. (1996) in common carp after exposure with glyphosate. In addition, Sharma (1999), Ghorpade et al. (2002) and Yildirim et al. (2006) reported similar results, but with other fish species and pesticides. The obtained results on the increase of the transaminases activity could be due to changes in the protein and carbohydrate metabolism. According to Naveed et al. (2004) the increased ALAT and ASAT activity shows the inclusion of amino acids in their transformation into keto acids or in the process of gluconeogenesis, which in turn is an indicator of liver damage. On the other hand, Begum (2004) and Li et al. (2004) found decreased levels of ALAT and ASAT in the fish liver under the influence of pesticides.

Given our previous studies (unpublished data) associated with an increased glycogen amount in the liver of common carp under the fungicide influence, we consider that the 
increased hepatic levels of LDH and ALAT probably lead to stimulation of the process of gluconeogenesis and glycogen accumulation in the fish liver.

On the contrary, the decreased activity of LDH and ALAT, as well as the reduced amount of glycogen in the fish exposed to the tested herbicide, suggest a reverse process of increased blood glucose due to the process of glycogenolysis (Stoyanova et al., 2014). This process is most likely a result of energy depletion after the stress, which the toxicants cause in the fish organism.

\section{Conclusions}

Overall, we consider that the bighead carp is a cyprinid species, which is not very resilient to pesticide contamination. Therefore, a regular monitoring on fish ponds near agricultural lands needs to be carried out. In the present study the two tested pesticides had a similar mode of action in terms of causing toxic effects such as histological alterations and biochemical disturbances in the fish liver. However, it seems that the fungicide caused more severe hepatic lesions. Even though, our experiment was performed only once we consider that the results on the hepatic histological and biochemical changes show that these alterations can be successfully applied as biomarkers for hepatotoxicity in biomonitoring and risk assessment programs on pesticide contaminated freshwater ecosystem. We, therefore suggest that further research in this particular area should be going on.

Acknowledgments. This paper is supported by the NPD - Plovdiv University "Paisii Hilendarski" under Grant No YS15-BF-004/22.04.2015.

\section{REFERENCES}

[1] Almeida, J.A., Diniz, Y.S., Marques, S.F.G., Faine, A., Ribas, B.O., Burneiko, R.C., Novelli, E. I.B. (2002): The use of the oxidative stress responses as biomarkers in Nile tilapia (Oreochromis niloticus) exposed to in vivo cadmium contamination. Environment International 27: 673-679.

[2] Almeida, J.R., Oliveira, C., Gravato, C., Guilhermino, L. (2010): Linking behavioural alterations with biomarkers responses in the European seabass Dicentrarchus labrax L. exposed to the organophosphate pesticide fenitrothion. - Ecotoxicology 19(8): 1369-1381.

[3] APHA. (2005): Standard methods for examination of water and wastewater, $21^{\text {st }}$ ed. Washington: American Public Health Association 1368 p.

[4] Au, D.W.T. (2004): The application of histo-cytopathological biomarkers in marine pollution monitoring: A review. - Marine Pollution 48: 817-834.

[5] Balint, T., Ferenczy, J., Katai, F. (1997): Similarities and differences between the massive eel (Anguilla anguilla L.) devastations that occurred in lake Balaton in 1991 and 1995. Ecotoxicology and Environmental Safety 37: 17-23.

[6] Banaee, M., Mirvaghefi, A.R., Sureda, A., Rafei, G.R., Ahmadi, K. (2012): Effect of sublethal concentrations of diazinon on blood parameters and liver histopathology of rainbow trout (Oncorhynchus mykiss). - Iranian Journal of Natural Resources 65(3): 297-313.

[7] Banaee, M., Davoodi, M.H., Zoheiri, F. (2013a): Histopathological changes induced by paraquat on some tissues of gourami fish (Trichogaster trichopterus). - Open Veterinary Journal 3(1): 36-42.

[8] Banaee, M., Sureda, A., Mirvaghefi, A.R., Ahmadi, K. (2013b): Biochemical and histological changes in the liver tissue of rainbow trout (Oncorhynchus mykiss) exposed 
to sub-lethal concentrations of diazinon. - Fish Physiology and Biochemistry 39: 489501.

[9] Begum, G. (2004): Carbofuran insecticide induced biochemical alterations in liver and muscle tissues of fish Clarias batrachus (Linn) and recovery response. - Aquatic Toxicology 66(1): 83-92.

[10] Bradford, M. (1976): A rapid and sensitive method for the quantitation of microgram quantities of protein using the principle of protein dye binding. - Analytical Biochemistry 72: 248-254.

[11] Bruslé, J., Gonzalez, G. (1996): The structure and function of fish liver. - In: Munshi, J. S. D, Dutta, H.M. (eds.) Fish Morphology, Science Publishers Inc., New York.

[12] Carvalho Neta, R.N.F., Sousa, D.B.P., de Almeida, Z.S., Santos, D.M.S., Tchaicka, L. (2014): A histopathological and biometric comparison between catfish (Pisces, Ariidae) from a harbor and a protected area, Brazil. - Aquatic Biosystems 10: 12.

[13] Das, K.B., Mukherjee, C.S. (2003): Toxicity of cypermethrin in Labeo rohita fingerlings: biochemical, enzymatic and haematological consequences. - Comparative Biochemistry and Physiology 134: 109-121.

[14] Devault, D.A., Gérino, M., Laplanche, C., Julien, F., Winterton, P., Merlina, G., Delmas, F., Lim, P., Miguel Sánchez-Pérez, J., Pinelli, E. (2009): Herbicide accumulation and evolution in reservoir sediments. - Science of Total Environment 407: 2659-2665.

[15] Directive 2010/63/EU of the European Parliament and of the Council of 22 September 2010 on the protection of animals used for scientific purposes. - Official Journal of the European Union.

[16] European Water Framework Directive. (2001): Decision 2455/2001/EC of 20 November 2001 establishing a list of priority substances in the field of water policy. - Official Journal of the European Union.

[17] European Food Safety Authority (EFSA). (2006): Conclusion on the peer review of the pesticide risk assessment of the active substance fosetyl, Parma, Italy.

[18] Fazio, F., Faggio, C., Marafioti, S., Torre, A., Sanfilippo, M., Piccione, G. (2013): Effect of water quality on hematological and biochemical parameters of Gobius niger caught in Faro Lake (Sicily). - Iranian Journal of Fisheries Sciences 12(1): 219-231.

[19] Franz, J.E. (1985): Discovery, development and chemistry of glyphosate. - In: Grossbard, E., Atkinson, D. (eds.) The Herbicide Glyphosate, Butterworth \& Co, London, 3-17 p.

[20] Fulton, M.H., Key P.B. (2001): Acetylcholinesterase inhibition in estuarine fish and invertebrates as an indicator of organophosphorus insecticide exposure and effects. Environmental Toxicology and Chemistry 20: 37-45.

[21] Gabriel, U.U., George, A.D. (2005): Plasma enzymes in C. gariepinus exposed to chronic levels of roundup (glyphosate). - Environmental Ecology 23: 271-276.

[22] Gabriel, U.U., Akinrotimi, O.A., Ariweriokuma, V.S. (2012): Changes in metabolic enzymes activities in selected organs and tissue of Clarias gariepinus exposed to cypermethrin. - Journal of Environmental Engineering and Technology 1(2): 25-30.

[23] Genix, P., Guesnet, J.L., Lacroix, G. (2003): Fenamidone - chimie and stereochimie. Pflanzenschutz-Nachrichten Bayer 56: 421-434.

[24] Ghorpade, N., Mehta, V., Khare, M., Sinkar, P., Krishnan, S., Rao, C. (2002): Toxicity study of diethyl phthalate on freshwater fish Cirrhina mrigala. - Ecotoxicology and Environmental Safaty 53: 255-258.

[25] Hermoso, V., Clavero, M., Blanco-Garrido, F., Prenda, J. (2010): Assessing the ecological status in species-poor systems: A fish-based index for Mediterranean Rivers (Guadiana River, SW Spain). - Ecological Indicators 10(6): 1152-1161.

[26] IFCC (International Federation of Clinical Chemistry). (1986): Methods for the measurement of catalytic concentration of enzymes, Part 2, IFCC method for aspartate aminotransferase (L aspartate: 2-oxogluarate aminotransferase, EC 2.6.1.1). - Journal of Clinical Chemistry and Clinical Biochemistry 24: 497-510. 
[27] Jiraungkoorskul, W., Upatham, E.S., Kruatrachue, M., Sahaphong, S., Vichasri-Grams, S., Pokethitiyook, P. (2003): Biochemical and histopathological effects of glyphosate herbicide on Nile tilapia (Oreochromis niloticus). - Environmental Toxicology 19: 260267.

[28] Koenig, S., Fernández, P., Solé, M. (2012): Differences in cytochrome P450 enzyme activities between fish and crustacean: relationship with the bioaccumulation patterns of polychlorobiphenyls (PCBs). - Aquatic Toxicology 108: 11-17.

[29] Kroglund, F., Rosseland, B.O., Teien, H.-C., Salbu, B., Kristensen, T., Finstad, B. (2008): Water quality limits for Atlantic salmon (Salmo salar L.) exposed to short term reductions in $\mathrm{pH}$ and increased aluminum simulating episodes. - Hydrology and Earth System Sciences 12: 491-507.

[30] Leake, C.R. (2003): Fenamidone: metabolism in plants. - Pflanzenschutz-Nachrichten Bayer 56: 533-546.

[31] Li, Z.H., Zlabete, V., Velisek, J., Grabic, R., Machova, J., Rendak, T. (2004): Physiological condition status and muscle based biomarkers in rainbow trout after long exposure to carbamazopine. - Journal of Applied Toxicology 30: 197-203.

[32] Loos, R., Gawlik, B.M., Locoro, G., Rimaviciute, E., Contini, S., Bidoglio, G. (2009): EU-wide survey of polar organic persistent pollutants in European river waters. Environmental Pollution 157: 561-568.

[33] Lu, Y., Zhang, A., Li, C., Zhang, P., Su, X., Li, Y., Mu, C., Li, T. (2013): The link between selenium binding protein from Sinonovacula constricta and environmental pollutions exposure. - Fish and Shellfish Immunology 35: 271-277.

[34] Malarvizhi, A., Kavitha, C., Saravanan, M., Ramesh, M. (2012): Carbamazepine (CBZ) induced enzymatic stress in gill, liver and muscle of a common carp, Cyprinus carpio. Journal of King Saud University - Science 24: 179-186.

[35] Marin-Morales, M.A., De Campos Ventura-Camargo, B., Hoshina, M.M. (2013): Toxicity of herbicides: impact on aquatic and soil biota and human health. - In: Price, A., Kelton, J.A. (eds.) Herbicides - Current Research and Case Studies in Use, In Tech, Croatia, 399-443 p.

[36] Mishra, R., Shukla, S.P. (1997): Impact of endosulfan on lactate dehydrogenase from the freshwater catfish Clarias batrachus. - Pesticide Biochemistry and Physiology 57(3): 220-234.

[37] Mohamed, F.A.S. (2009): Histopathological studies on Tilapia zillii and Solea vulgaris from Lake Qarun, Egypt. - World Journal of Fish and Marine Sciences 1(1): 29-39.

[38] Morowati, M. (1997): Inhalation toxicity studies of thimet (phorate) in mall Swiss albino mouse, Mus musculus: hepatotoxicity. - Environmental Pollution 96(3): 283-288.

[39] Naveed, A., Venkateshwarlu, P., Janaiah, C. (2004): The action of sublethal concentration of endosulfan and kelthane on regulation of protein metabolism in the fish Clarias batrachus. - Nature Environment and Pollution Technology 3(4): 539-544.

[40] Neškovic, N.K., Poleksic, V., Elezovic, I., Karan, V., Budimir, M. (1996): Biochemical and histopathological effects of glyphosate on carp, Cyprinus carpio L. - Bulletin of Environmental Contamination and Toxicololy 56: 295-302.

[41] Pierce, K.W., McCain, B.B., Wellings, S.R. (1978): Pathology of hepatomas and other liver abnormalities in English sole (Parophrys vetulus) from the Duwamish river estuary, Seattle, Washington. - Journal of National Cancer Institute 60(6): 1445-1543.

[42] Reemtsma, T., Weiss, S., Mueller, J., Petrovic, M., Gonzalez, S., Barcelo, D., Ventura, F., Knepper, T.P. (2006): Polar pollutants entry into the water cycle by municipal wastewater: an European perspective. - Environmental Science and Technology 40: 54515458.

[43] Reitman, S., Frankel, S. (1957): A colorimetric method for the determination of serum glutamic oxaloacetic and glutamic pyruvic transaminases. - American Journal of Clinical Pathology 28: 56-63. 
[44] Romeis, B. (1989): Mikroskopische Technik. - Urban und chwarzenberg, München, 697 p.

[45] Schwaiger, J., Wanke, R., Adam, S., Pawert, M., Honnen, W., Triebskorn, R. (1997): The use of histopathological indicators to evaluate contaminant-related stress in fish. - Journal of Aquatic Ecosystems and Stress Recovery 6: 75-86.

[46] Schwarzenbach, R.P., Escher, B.I., Fenner, K., Hofstetter, T.B., Johnson, C.A., Von Gunten, U., Wehrli, B. (2006): The challenge of micropollutants in aquatic systems. Science 313: 1072-1077.

[47] Sepici-Dincel, A., Karasu, B.C., Selvi, M., Sarikaya, R., Sahih, D., Ozkul, I.A., Erkve, F. (2009): Sublethal cyfluthrin to carp Cyprinus carpio fingerlings: biochemical, hematological, histopathological alterations. - Ecotoxicology and Environmental Safety 72: 1433-1439.

[48] Sharma, B. (1999): Effect of carbaryl on some biochemical constituents of the blood and liver of Clarias batrachus, a fresh-water teleost. - Journal of Toxicological Sciences 24(3): 157-164.

[49] Solé, M., Porte, C., Barcelo, D., Albaiges, J. (2000): Bivalves residue analysis for the assessment of coastal pollution in the Ebro Delta (NW Mediterranean). - Marine Pollution Bulletin 40(9): 746-753.

[50] Statistica version 7.0 for Windows (2004): StatSoft, Part of Dell Software.

[51] Stentiford, G.D., Longshaw, M., Lyons, B.P., Jones, G., Green, M., Feist, S.W. (2003): Histopathological biomarkers in estuarine fish species for the assessment of biological effects of contaminants. - Marine Environmental Research 55: 137-159.

[52] Stoyanova, S., Yancheva, V., Velcheva, I., Atanasova, P., Georgieva, E. (2014): Hypoglycaemic effects of glyphosate based herbicide on common carp and bighead carp liver. - Proceedings in Seminar of Ecology Sofia, Bulgaria; 88-89 p.

[53] Sun, X., Zhu, F., Xi, J., Lu, T., Liu, H., Tong, Y., Ouyang, G. (2011): Hollow fiber liquid-phase microextraction as clean-up step for the determination of organophosphorus pesticides residues in fish tissue by gas chromatography coupled with mass spectrometry. - Marine Pollution Bulletin 63: 102-107.

[54] Takashima, F., Hibiya, T. (1995): An atlas of fish histology: normal and pathological features, $2^{\text {nd }}$ ed. - Kodansha Ltd, Tokyo.

[55] Valbonesi, P., Brunelli, F., Mattioli, M., Rossi, T., Fabbri, E. (2011): Cholinesterase activities and sensitivity to pesticides in different tissues of silver European eel, Anguilla Anguilla. - Comparative Biochemistry and Physiology Part C 154(4): 353-359.

[56] Van der Oost, R., Beyer, J., Vermeulen, N.P.E. (2003): Fish bioaccumulation and biomarkers in environmental risk assessment: A review. - Environmental Toxicology and Pharmacology 13: 57-149.

[57] Van Dyk J.C., Pieterse, G.M. (2008): A histo-morphological study of the testis of the sharptooth catfish (Clarias gariepinus) as reference for future toxicological assessments. Journal of Applied Ichthyology 24: 415-422.

[58] Van Dyk, J.C., Marchand, M.J., Smit, N.J., Pieterse, G.M. (2009): A histology-based fish health assessment of four commercially and ecologically important species from the Okavango Delta panhandle, Botswana. - African Journal of Aquatic Sciences 34: 273282.

[59] Vassault, A. (1983): Lactate dehydrogenase. - In: Bergmeyer, M.O. (ed.) Methods of enzymatic analysis, enzymes: oxireductases, transferases, Academic Press, New York.

[60] Velmurugan, B., Selvanayagam, M., Cengiz, E., Uysal, E. (2008): Levels of transaminases, alkaline phosphatase, and protein in tissues of Clarias gariepienus fingerlings exposed to sub-lethal concentrations of cadmium chloride. - Environmental Toxicology 23: 672-678.

[61] Velmurugan, B., Selvanayagam, M., Cengiz, E.I., Unlu, E. (2009): Histopathological changes in the gill and liver tissues of freshwater fish, Cirrhinus mrigala exposed to dichlorvos. - Brazilian Archives of Biology and Technology 52(5): 1291-1296. 
[62] Viana, A.P., Frédou, F.L., Da Silva Montes, C., Rocha, R.M. (2013): Fish histopathology and catalase activity as biomarkers of the environmental quality of the industrial district on the Amazon estuary, Brazil. - Acta Scientiarum 35(3): 395-401.

[63] Yadav, A.S., Bhatnagar, A., Kaur, M. (2010): Assessment of genotoxic effects of butachlor in fresh water fish, Cirrhinus mrigala (Hamilton). - Research Journal of Environmental Toxicology 4: 223-230.

[64] Yildirim, M.Z., Benli, K.C., Selvi, M., Ozkul, A., Erko, F., Kocak, O. (2006): Acute toxicity behavioural changes and histopathological effects of deltamethrin on tissues (gills, liver, brain, spleen, kidney, muscle, skin) of Nile Tilapia (Oreochromis niloticus) fingerlings. - Environmental Toxicology 21: 614-620.

[65] Yousafzai, M.A., Shakoori, R.A. (2011): Hepatic response of a fresh water fish against aquatic pollution. - Pakistan Journal of Zoology 43(2): 209-221.

[66] Zhou, R., Zhu, L., Chen, Y., Kong, Q. (2008): Concentrations and characteristics of organochlorine pesticides in aquatic biota from Qiantang River in China. - Environmental Pollution 151: 190-199.

[67] Zimmerli, S., Bernet, D., Burkhardt-Holm, P., Schmidt-Posthaus, H., Vonlanthen, P., Wahli, T., Segner, H. (2007): Assessment of fish health status in four Swiss rivers showing a decline in brown trout catches. - Aquatic Sciences 69: 11-25. 